\title{
The role of the AR/ER ratio in ER-positive breast cancer patients
}

\author{
Nelson Rangel1,2, Milena Rondon-Lagos³, Laura Annaratone', Simona Osella-Abate1, Jasna Metovic, \\ Maria Piera Mano4, Luca Bertero', Paola Cassoni', Anna Sapino1,5 and Isabella Castellano \\ 'Department of Medical Sciences, University of Turin, Turin, Italy \\ ${ }^{2}$ Natural and Mathematical Sciences Faculty, Universidad del Rosario, Bogotá, Colombia \\ 3School of Biological Sciences, Universidad Pedagógica y Tecnológica de Colombia, Tunja, Colombia \\ ${ }^{4}$ Department of Surgical Sciences, University of Turin, Turin, Italy \\ 5Pathology Unit, Fondazione del Piemonte per I'Oncologia (FPO) Candiolo Cancer Institute (IRCCS), Candiolo, Italy
}

Correspondence should be addressed to I Castellano: isabella.castellano@unito.it

\begin{abstract}
The significance of androgen receptor (AR) in breast cancer (BC) management is not fully defined, and it is still ambiguous how the level of AR expression influences oestrogen receptor-positive $(E R+)$ tumours. The aim of the present study was to analyse the prognostic impact of AR/ER ratio, evaluated by immunohistochemistry (IHC), correlating this value with clinical, pathological and molecular characteristics. We retrospectively selected a cohort of $402 \mathrm{ER}+\mathrm{BC}$ patients. On each tumour, IHC analyses for AR, ER, PgR, HER2 and Ki67 were performed and AR+ cases were used to calculate the AR/ER value. A cut-off of $\geq 2$ was selected using receiver-operating characteristic (ROC) curve analyses. RNA from 19 cases with $A R / E R \geq 2$ was extracted and used for Prosigna-PAM50 assays. Tumours with $A R / E R \geq 2(6 \%)$ showed more frequent metastatic lymph nodes, larger size, higher histological grade and lower PgR levels than cases with $A R / E R<2$. Multivariate analysis confirmed that patients with $A R / E R \geq 2$ had worse disease-free interval (DFI) and disease-specific survival (DSS) (hazard ratios (HR) $=4.96$ for DFI and $H R=8.69$ for DSS, both $P \leq 0.004)$. According to the Prosigna-PAM50 assay, $63 \%(12 / 19)$ of these cases resulted in intermediate or high risk of recurrence categories. Additionally, although all samples were positive for ER assessed by IHC, the molecular test assigned $47.4 \%$ (9/19) of $B C s$ to intrinsic non-luminal subtypes. In conclusion, the AR/ER ratio $\geq 2$ identifies a subgroup of patients with aggressive biological features and may represent an additional independent marker of worse BC prognosis. Moreover, the Prosigna-PAM50 results indicate that a significant number of cases with $A R / E R \geq 2$ could be non-luminal tumours.
\end{abstract}

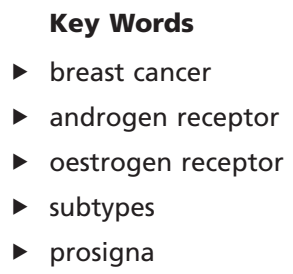

Endocrine-Related Cancer (2018) 25, 163-172

\section{Introduction}

Oestrogen receptor (ER) and progesterone receptor (PgR) are expressed in most breast cancers (BCs) $(\sim 75 \%)$ and both have wide prognostic and predictive utility (Early Breast Cancer Trialists' Collaborative Group 2011). In contrast, the clinical and biological significance of androgen receptor (AR) expression in BC is not fully defined. AR positivity has been detected in up to $61 \%$ of primary and metastatic BC lesions (Park et al. 2010, Hu et al. 2011, Yu et al. 2011) and approximately 75\% of ER-positive (ER+) BCs are also AR positive (AR+). Several studies have shown that AR expression in luminal tumours $(\mathrm{ER}+)$ is associated with lower tumour 
grade, smaller tumour size, lower proliferative index (Ki67 level) and more importantly, AR expression in ER+ tumours is an independent prognostic factor of a good outcome (Castellano et al. 2010, Niemeier et al. 2010, Aleskandarany et al. 2016, Bozovic-Spasojevic et al. 2016). On the other hand, up to $31 \%$ of ER-negative (ER-) BCs are reported to be AR+ (Niemeier et al. 2010, Park et al. 2010), but the prognostic impact of AR expression in this subset of BCs is not clear (Luo et al. 2010, Hu et al. 2011, Park et al. 2011, Pistelli et al. 2014, Vera-Badillo et al. 2014, Hilborn et al. 2016, Jiang et al. 2016, Asano et al. 2017).

While the interaction between the signalling pathways of ER and AR (Peters et al. 2009) is well known, it is still ambiguous how the level of AR expression influences ER+ tumours. In vitro studies have shown that AR signalling inhibits oestrogen-induced proliferation of ER+ MCF7 BC cells (Ando et al. 2002, Greeve et al. 2004, Macedo et al. 2006, Cops et al. 2008). This inhibitory effect seems to be mediated by several mechanisms, but the most important is the ability of AR to compete with ER for binding of oestrogen response elements (EREs), preventing ER-dependent gene transcription (Need et al. 2012). In line with this observation, some studies have reported that increasing AR expression results in a greater androgen-dependent inhibition of ER function (Buchanan et al. 2005, Peters et al. 2009). However, other studies performed on ER+ MCF7 BC cells described an increase in proliferation when the AR signalling pathway is stimulated (Birrell et al. 1995, Lin et al. 2009). Moreover, Cochrane and coworkers (Cochrane et al. 2014) recently reported that high AR levels and low ER levels (higher AR/ER ratio) could be associated with a worse prognosis and tamoxifen (TAM) resistance.

Considering these data, the aim of the present study was to analyse the prognostic impact of AR expression with respect to ER (AR/ER ratio) in a large case series of ER+/HER2-negative (HER2-) BC patients. We evaluated if the AR/ER ratio may identify a subset of tumours with different clinical and pathological characteristics. In addition, in the subgroup of BCs with high AR/ER ratio values, we performed Prosigna-PAM50 assays to assess the molecular subtypes of these BCs.

\section{Patients and methods}

\section{Study design and population}

We collected a cohort of $402 \mathrm{ER}+$ /HER2- primary invasive BC patients with available follow-up (Fig. 1), who underwent surgery from January 1998 to December 2012 at the Breast Unit of the Città della Salute e della Scienza of Torino, University Hospital of Torino in Turin, Italy. In the diagnostic setting, the cut-off value considered for ER and PgR positivity was $\geq 1 \%$, as suggested by the St Gallen and ASCO/CAP Guideline Recommendations (Hammond et al. 2010, Coates et al. 2015), and the same cut-off was adopted for AR positivity (Castellano et al. 2010). For all cases, the following clinico-pathological data were obtained from the clinical charts and pathological reports: age, type of surgery (conservative surgery vs radical mastectomy), tumour size $(<15 \mathrm{~mm}$ vs $\geq 15 \mathrm{~mm})$, histological type, tumour grade and nodal involvement. Ethical approval for this study was obtained from the Comittee for human Biospecimen Utilization (Department of Medical Sciences - ChBU). The project provided an informed consent, obtained from the patients at the time of surgery due to the retrospective approach of the study, which did not impact on their treatment. The procedure for collecting the consent was approved by the Committee for human Biospecimen Utilization (Department of Medical Sciences - ChBU). All the cases were anonymously recorded, and data were accessed anonymously.

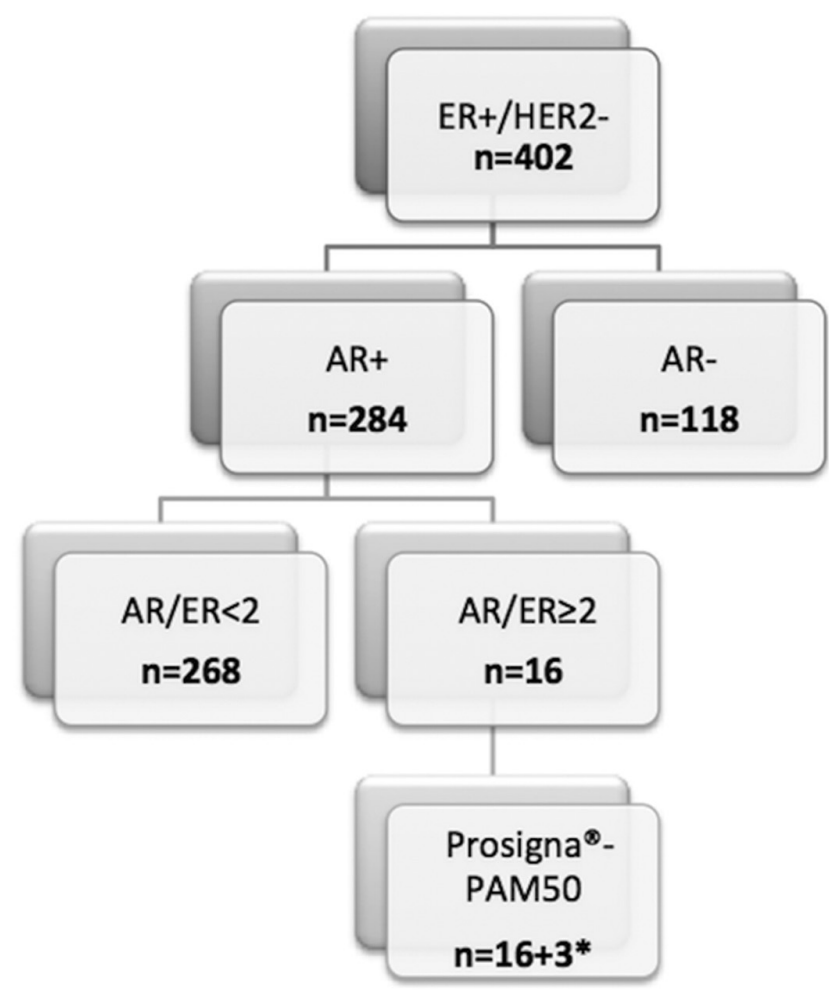

Figure 1

Study flowchart. ER - estrogen receptor; HER2 - human epidermal growth factor receptor 2; AR -androgen receptor. *Three additional cases (without follow-up) with a ratio of $A R / E R \geq 2$ were included for the Prosigna-PAM50 assay. 


\section{Immunohistochemistry (IHC)}

For each case, representative blocks were selected and multicore tissue microarrays (TMAs) were prepared, as previously described (Sapino et al. 2006). IHC was performed using an automated slide processing platform (Ventana BenchMark AutoStainer, Ventana Medical Systems, Tucson, AZ, USA) with the following primary antibodies: prediluted anti-ER rabbit monoclonal antibody (SP1, Ventana Medical Systems); prediluted anti-PgR rabbit monoclonal antibody (1E2, Ventana Medical Systems); anti-AR mouse monoclonal antibody (AR441, diluted 1:50, Dako) and anti-Ki67 mouse monoclonal antibody (MIB1, diluted 1:50, Dako). Measurement of HER2 expression was performed by an anti-HER2 polyclonal antibody (A0485, diluted 1:800, Dako). IHC equivocal cases (score 2+) were assessed for HER2 status by fluorescence in situ hybridization (FISH) (Marchio et al. 2009). Positive and negative controls (omission of the primary antibody and IgG-matched serum) were included for each immunohistochemical run. All cases were confirmed as ER+ and HER2-.

For statistical analyses and according to the St Gallen Consensus Recommendations (Coates et al. 2015), we adopted a cut-off of $20 \%$ for dichotomizing tumours as having low and high levels of PgR and Ki67. In addition, this cut-off agrees with the median Ki67 value of our laboratory, previously established to differentiate tumours with a higher proliferative index (Coates et al. 2015, Bustreo et al. 2016).

\section{AR/ER ratio calculation}

$\mathrm{AR}$ and ER nuclear staining percentages were compared. Post estimation ROC curve after logistic regression was used to establish the optimal AR/ER ratio cut-off value, which allowed us to subdivide the patients into those with good and worse prognosis as described below.

\section{Statistical analyses}

Pearson's chi-square test and Student's t-test were preliminarily performed to compare categorical and continuous variables, respectively, and to evaluate the potential differences in the variable distribution among the groups. The disease-free interval (DFI) was calculated from the date of surgical excision of the primary tumour to the date of the first relapse or last check-up. Diseasespecific survival (DSS) was calculated from the surgical excision date of the primary tumour to the date of $\mathrm{BC}$ death or last check-up. Survival distribution curves were plotted using the Kaplan-Meier method and the statistical comparisons were performed using the log-rank test. Cox regression analyses were carried out on the DFI and DSS to calculate the crude and adjusted HR and 95\% CIs for the different study group. The cases lost to follow-up and cases with non-breast cancer-related deaths were censored at the last follow-up. Models were created to evaluate the prognostic role of different variables. The proportional hazard assumption was assessed with the Schoenfeld residuals. This did not give reasons to suspect a violation of this assumption. The nature of the variables

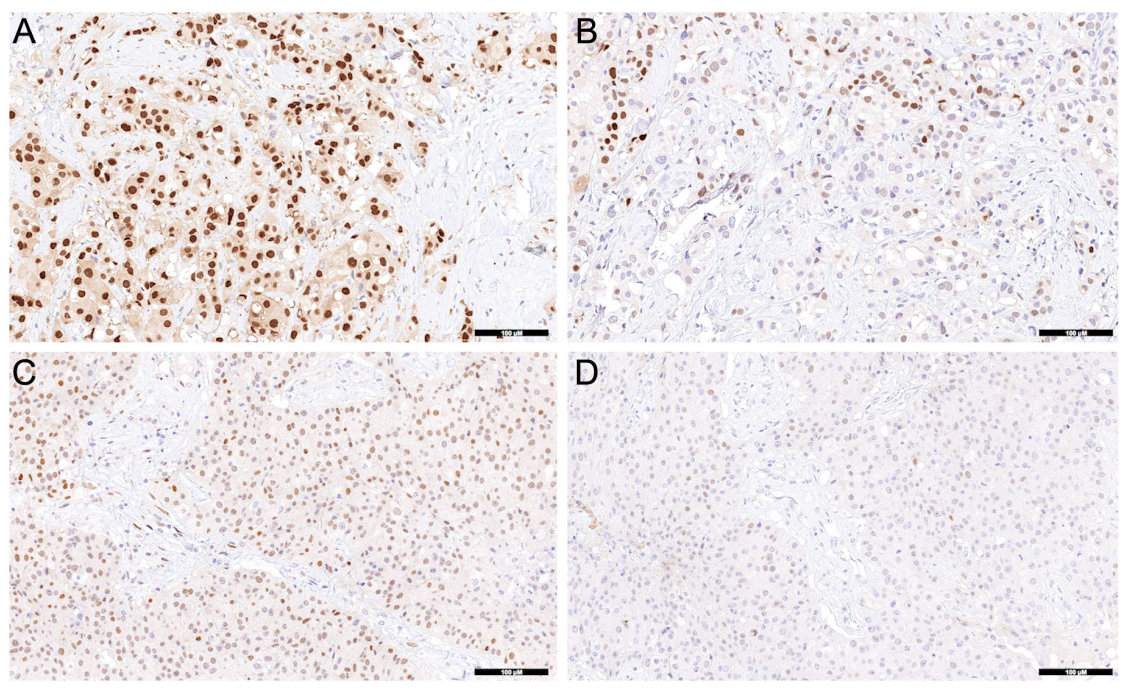

\section{Figure 2}

Immunohistochemical staining. Representative IHC for the androgen receptor ( $A$ and $C$ ) and estrogen receptor ( $B$ and $D$ ) in two $B C$ cases with high $A R$ levels with respect to $E R(A R / E R \geq 2)$. Although ER is expressed at the IHC level in these cases, the molecular test classified them as non-luminal subtypes. 
Table 1 Clinical and pathological characteristics of ER+/AR+BC patients.

\begin{tabular}{l} 
Clinical-pathological features \\
\hline Number of patients \\
Median age (interval) \\
ER\% median (interval) \\
AR\% median (interval) \\
Grade \\
1 \\
2 \\
3 \\
Tumour size \\
$<15$ mm \\
$\geq 15$ mm \\
Metastatic lymph nodes \\
0 \\
$1-3$ \\
$4-9$ \\
$>9$ \\
Ki67 \\
$<20 \%$ \\
$\geq 20 \%$ \\
PgR \\
$<20 \%$ \\
$\geq 20 \%$ \\
Relapse \\
No \\
Local \\
Distant \\
Surgery \\
Quadrantectomy \\
Mastectomy \\
Therapy \\
HT \\
CT \\
\end{tabular}

\begin{tabular}{c}
\hline Total $(\%)$ \\
\hline $284(100)$ \\
$62(31-88)$ \\
$90(2-100)$ \\
$50(5-99)$
\end{tabular}

\begin{tabular}{c}
\hline AR/ER<2 (\%) \\
\hline $268(94.3)$ \\
$62(31-87)$ \\
$95(30-100)$ \\
$40(5-99)$
\end{tabular}

\begin{tabular}{|c|c|}
\hline$A R / E R \geq 2(\%)$ & $\boldsymbol{P}$ value (Fisher test) \\
\hline $16(5.7)$ & - \\
\hline $65(47-88)$ & 0.309* \\
\hline $18(2-45)$ & $<0.001 *$ \\
\hline 80 (25-99) & 0.01 * \\
\hline
\end{tabular}

$\begin{array}{llll}104(36.7) & 103(38.4) & 1(6.3) & <0.001 \\ 128(45) & 122(45.5) & 6(37.5) & \end{array}$

$128(45)$

$52(18.3)$

$43(16.1)$

149 (52.5)

$135(47.5)$

$146(54.5)$

$122(45.5)$

$191(67.2)$

$62(21.8)$

$22(7.8)$

9 (3.2)

168 (59.2)

$116(40.8)$

$183(68.3)$

$61(22.8)$

$18(6.8)$

$6(2.1)$

$9(56.2)$

$3(18.7)$

0.004

$13(81.3)$

$8(50)$

1 (6.3)

4 (25)

3 (18.7)

$162(60.4)$

$106(39.6)$

6 (37.5)

0.075

42 (14.8)

242 (85.2)

$33(12.3)$

235 (87.7)

$10(62.5)$

9 (56.3)

7 (43.7)

$233(82)$

5 (1.8)

46 (16.2)

225 (84)

5 (1.9)

$38(14.1)$

8 (50)

0

$8(50)$

$188(66.2)$

181 (67.5)

87 (32.5)

7 (43.7)

9 (56.3)

198 (69.7)

190 (70.9)

8 (50)

77 (28.7)

$<0.001$

85 (29.4)

Patients were grouped according to AR/ER ratio cut-off $\geq 2$.

${ }^{*} P$ value from Student's $t$-test; ${ }^{+1}$ patient refused therapy.

$\mathrm{CT}$, patients who received hormonal therapy plus chemotherapy; HT, patients who received hormonal therapy.

Table 2 Univariate analysis in the group of ER+/AR+ BC patients.

\begin{tabular}{|c|c|c|c|c|}
\hline \multirow[b]{2}{*}{ Clinical-pathological features } & \multicolumn{2}{|c|}{ DFI } & \multicolumn{2}{|l|}{ DSS } \\
\hline & $\mathrm{HR}(95 \% \mathrm{Cl})$ & $P$ & $\mathrm{HR}(95 \% \mathrm{Cl})$ & $P$ \\
\hline Age & $0.99(0.96-1.02)$ & 0.694 & $0.970 .93-1.01$ & 0.264 \\
\hline Grade & $3.02(1.96-4.66)$ & $<0.001$ & $5.26(2.37-11.7)$ & $<0.001$ \\
\hline Tumor size $\geq 15 \mathrm{~mm}$ & $6.97(3.22-15.06)$ & $<0.001$ & $11.9(2.74-52)$ & $<0.001$ \\
\hline \multicolumn{5}{|l|}{ Metastatic lymph nodes } \\
\hline 0 & 1 & & & \\
\hline $1-3$ & $2.92(1.37-6.23)$ & $<0.005$ & $2.85(0.71-11.4)$ & 0.138 \\
\hline $4-9$ & $5.58(2.41-12.9)$ & $<0.001$ & $12.2(3.44-43.3)$ & $<0.001$ \\
\hline$>9$ & $15.5(6.25-38.6)$ & $<0.001$ & $23.17(5.74-93.3)$ & $<0.001$ \\
\hline$K i 67 \geq 20 \%$ & 7.66 (3.55-16.52) & $<0.001$ & $12.25(2.81-53.3)$ & $<0.001$ \\
\hline$P g R \geq 20 \%$ & $0.65(0.34-1.25)$ & 0.201 & $0.77(0.27-2.16)$ & 0.061 \\
\hline ER\% expression & $0.98(0.97-0.99)$ & 0.027 & $0.98(0.96-0.99)$ & 0.016 \\
\hline AR\% expression & $1.00(0.99-1.01)$ & 0.541 & $0.99(0.98-1.02)$ & 0.994 \\
\hline$A R / E R \geq 2$ & $7.55(3.31-17.2)$ & $<0.001$ & $10.84(3.52-33.3)$ & $<0.001$ \\
\hline $\mathrm{HT}$ vs $\mathrm{CT}$ & $3.77(2.02-7.03)$ & $<0.001$ & $3.85(1.42-10.42)$ & 0.008 \\
\hline
\end{tabular}

CT, patients who received hormonal therapy plus chemotherapy; DFI, disease-free interval; DSS, disease-specific survival; HR, hazard ratio; HT, patients who received hormonal therapy. 
(continue/categorical) included in the models was evaluated considering literature reports and the results of the log-likelihood ratio test. For model selection, the Akaike information criterion (AIC) test was used. All statistical tests were two-sided. $P$-values $<0.05$ were considered significant. Statistical analyses were performed using STATA/SE12.0 Statistical Software (STATA, College Station, TX, USA).

\section{Prosigna multigene prognostic assay}

Sixteen ER+/HER2 - BC cases with an AR/ER ratio $\geq 2$ with long follow-up and 3 additional cases collected during the routine diagnostic assessment of ER and AR were selected for Prosigna-PAM50 analysis (NanoString Technologies, Seattle, WA, USA). Briefly, tissue obtained after macrodissection of formalin-fixed paraffin-embedded (FFPE) tumours were processed with a Roche FFPET RNA Isolation Kit (Roche). The isolated RNA was hybridized to 58 gene-specific probe pairs, plus 6 positive and 8 negative controls (Capture and Reporter Probes - Prosigna CodeSet. NanoString Technologies), overnight at $65^{\circ} \mathrm{C}$ in a single hybridization reaction. The removal of excess probes, followed by binding of the probe-target complexes on the surface of a specific nCounter cartridge, was performed on the nCounter Prep Station (NanoString Technologies). Finally, the nCounter cartridge with immobilized probe/ target complexes was read in the nCounter Digital Analyzer (NanoString Technologies). The conversion of gene expression measurements into intrinsic molecular subtypes, risk of recurrence (ROR) scores and risk categories used a fully prespecified algorithm has been previously described (Parker et al. 2009, Dowsett et al. 2013).

\section{Results}

\section{Patients and tumour characteristics}

Clinical and pathological features of the $402 \mathrm{ER}+1$ HER2- tumours according to the AR status are shown in Supplementary Table 1 (see section on supplementary data given at the end of this article). The median time of follow-up was 8 years. The majority of cases, $70.6 \%$ (284/402), were AR+. The distribution plots of IHC ER and AR nuclear staining percentages are presented in Supplementary Fig. 1. According to our previous reports (Castellano et al. 2010, 2013), we confirmed that AR expression ( $\geq 1 \%$ nuclear staining) was significantly correlated with a longer DSS $(P=0,0008$; Supplementary Fig. 2) of ER+ BC patients.

\section{AR/ER ratio and correlation with histological and immunohistochemical features}

The median AR/ER ratio was 0.51. Two was the optimal $\mathrm{AR} / \mathrm{ER}$ ratio that differentiated the cohort by prognosis (AR/ER $\geq 2$ : $\mathrm{AUC}=0.74 ; P=0.002$ ) (Supplementary Fig. 3). The characteristics of the $284 \mathrm{ER}+/ \mathrm{HER} 2-/ \mathrm{AR}+\mathrm{BC}$ cases stratified by an AR/ER ratio cut-off are reported in Table 1. Of the $284 \mathrm{AR}+/ \mathrm{ER}+$ cases, 268 (94\%) had an AR/ER ratio $<2$ and $16(6 \%)$ an AR/ER ratio $\geq 2$ (Fig. 1 and Fig. 2). In the descriptive analysis, patients with a higher AR/ER ratio carried larger tumours with a higher histological grade and lower PgR levels, and they frequently had more metastatic lymph nodes and had a higher number of relapse events $(P \leq 0.004)$ (Table 1).
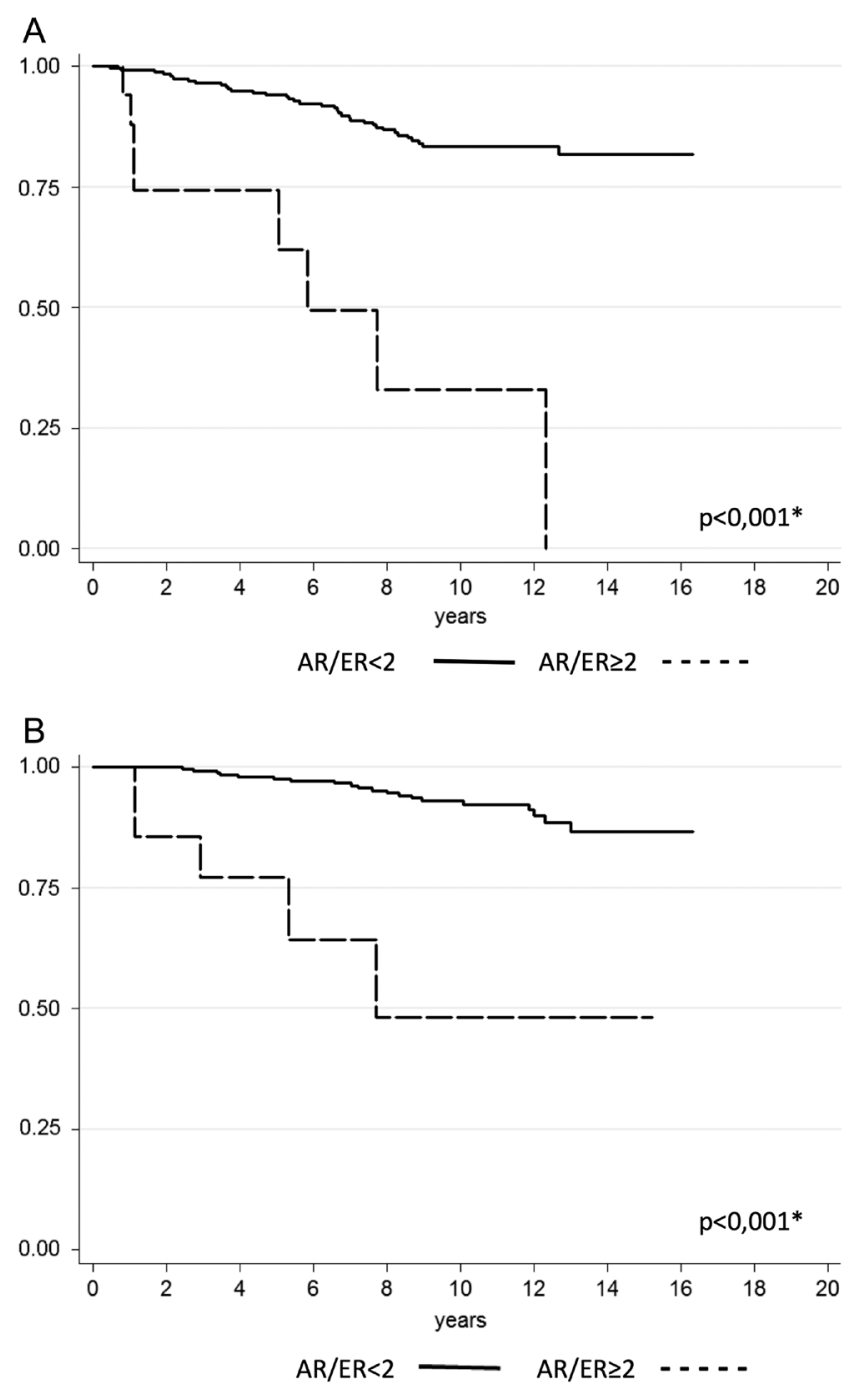

Figure 3

Survival curves for $A R / E R<2$ vs $A R / E R \geq 2$. (A) Disease-free interval (DFI). (B) Disease-specific survival (DSS). * Log-rank test for equality of survivor functions. 
Table 3 Multivariate analysis in the group of ER+/AR+BC patients.

\begin{tabular}{|c|c|c|c|c|}
\hline \multirow[b]{2}{*}{ Clinical-pathological features } & \multicolumn{2}{|c|}{ DFI* } & \multicolumn{2}{|l|}{ DSS* } \\
\hline & HR $(95 \% \mathrm{Cl})$ & $P$ & $\mathrm{HR}(95 \% \mathrm{Cl})$ & $P$ \\
\hline Age & $1.01(0.98-1.04)$ & 0.474 & $0.98(0.94-1.03)$ & 0.602 \\
\hline Tumor size $\geq 15 \mathrm{~mm}$ & $4.16(1.88-9.18)$ & $<0.001$ & $8.87(1.71-46)$ & 0.009 \\
\hline \multicolumn{5}{|l|}{ Metastatic lymph nodes } \\
\hline 0 & 1 & & & \\
\hline $1-3$ & $1.41(0.58-3.40)$ & 0.441 & $1.28(0.23-7.1)$ & 0.778 \\
\hline $4-9$ & $1.59(0.63-3.99)$ & 0.321 & $3.45(0.81-14.7) 7)$ & 0.095 \\
\hline$>9$ & $4.42(1.66-11.79)$ & 0.003 & $5.71(1.17-27.7)$ & 0.031 \\
\hline$K i 67 \geq 20 \%$ & $3.98(1.78-8.86)$ & $<0.001$ & $5.26(1.12-24.6)$ & 0.035 \\
\hline $\mathrm{AR} / \mathrm{ER} \geq 2$ & $4.96(1.95-12.68)$ & $<0.001$ & $8.69(2.02-37.44)$ & 0.004 \\
\hline HT vs $\mathrm{CT}$ & $1.64(0.72-7.03)$ & 0.234 & $1.02(0.25-4.18)$ & 0.974 \\
\hline
\end{tabular}

*Test of proportional-hazards assumption global test DFI $P=0.3188$, DSS $P=0.3871$.

$\mathrm{CT}$, patients who received hormonal therapy plus chemotherapy; DFI, disease-free interval; DSS, disease-specific survival; HR, hazard ratio; HT, patients who received hormonal therapy.

\section{AR/ER ratio and impact on prognosis}

As shown in Table 2, univariate analysis confirmed that an $\mathrm{AR} / \mathrm{ER}$ ratio $\geq 2$ was one of the most significant markers of poor survival (HR=7.55 for DFI, and $\mathrm{HR}=10.84$ for DSS, both $P<0.001)$, together with tumour grade, tumour size $\geq 15 \mathrm{~mm}$, nodal involvement $\geq 4$ and high Ki67 index. Moreover, the Kaplan-Meier curves and the logrank test showed significant differences in the survival times between the two groups (DFI and DSS $P<0.001$ ) (Fig. $3 \mathrm{~A}$ and $\mathrm{B}$ ). In the analysis, we also included ER and $\mathrm{AR}$ expression as continuous variables to compare the weight on the prognosis of different levels of the receptor expression with the AR/ER ratio. While the percentage of AR expression did not show any impact on prognosis, the levels of ER were correlated with prognosis although at a lower significance compared to the AR/ER ratio (Table 2). Multivariate analysis confirmed an independent effect on the prognosis of the AR/ER ratio. According to this model, patients with an $A R / E R \geq 2$ were five times more likely to relapse (HR $=4.96, P<0.001$ for $\mathrm{DFI}$ ) and eight times more likely to die of $\mathrm{BC}(\mathrm{HR}=8.69, P=0.004$ for DSS) compared with patients with a ratio $<2$. Tumour size $\geq 15 \mathrm{~mm}$, lymph nodes $>9$ and a high Ki67 index had an unfavourable effect on DFI and DSS (Table 3). The proportionality assumption was satisfied both for the DFI $(P=0.1227)$ and DSS $(P=0.3517)$.

To exclude the possibility that prognostic information from the AR/ER ratio was only a consequence of the low ER levels, we additionally tested a cut-off point for ER nuclear staining at $10 \%$. As expected, patients with lower ER levels $(<10 \%)$ were associated with worse DFI and DSS (Supplementary Fig. 4). However, according to the AIC
Table 4 Characteristics of BC cases evaluated with Prosigna - PAM50 assay.

\begin{tabular}{|c|c|}
\hline Clinical and molecular features & AR/ER $\geq 2 \boldsymbol{n}(\%)$ \\
\hline \multicolumn{2}{|l|}{ Grade } \\
\hline 1 & $1(5.3)$ \\
\hline 2 & $8(42.1)$ \\
\hline 3 & $10(52.6)$ \\
\hline \multicolumn{2}{|l|}{ Tumor size } \\
\hline$<15 \mathrm{~mm}$ & $5(26.3)$ \\
\hline$\geq 15 \mathrm{~mm}$ & $14(73.7)$ \\
\hline \multicolumn{2}{|l|}{ Metastatic lymph nodes } \\
\hline 0 & $11(57.9)$ \\
\hline $1-3$ & $1(5.3)$ \\
\hline $4-9$ & $4(21)$ \\
\hline$>9$ & $3(15.8)$ \\
\hline \multicolumn{2}{|l|}{ Ki67 } \\
\hline$<20 \%$ & $8(42.1)$ \\
\hline$\geq 20 \%$ & $11(57.9)$ \\
\hline \multicolumn{2}{|l|}{$\mathrm{PgR}$} \\
\hline$<20$ & $12(63.2)$ \\
\hline$\geq 20$ & 7 (36.8) \\
\hline \multicolumn{2}{|l|}{ IHC-based subtype } \\
\hline Luminal A & $3(15.8)$ \\
\hline Luminal B & $16(84.2)$ \\
\hline \multicolumn{2}{|c|}{ Prosigna-PAM50 molecular subtype } \\
\hline Luminal A & $9(47.4)$ \\
\hline Luminal B & $1(5.3)$ \\
\hline HER2-Enriched & $2(10.5)$ \\
\hline Basal-like & $7(36.8)$ \\
\hline \multicolumn{2}{|l|}{ Prosigna-PAM50 risk category } \\
\hline Low & $7(36.8)$ \\
\hline Intermediate & $4(21.1)$ \\
\hline High & $8(42.1)$ \\
\hline \multicolumn{2}{|c|}{ Prosigna-PAM50 risk category - $\mathrm{PDR}^{\dagger}$} \\
\hline Low & $7(4.57)^{*}$ \\
\hline Intermediate & $4(10.25)$ * \\
\hline High & $8(34.87) *$ \\
\hline
\end{tabular}

tProbability of distant recurrence; * Mean percentage of PDR at 10 years for each risk category. http://ercendocrinology-journals.org https://doi.org/10.1530/ERC-17-0417
(C) 2018 Society for Endocrinology Published by Bioscientifica Ltd. Printed in Great Britain 

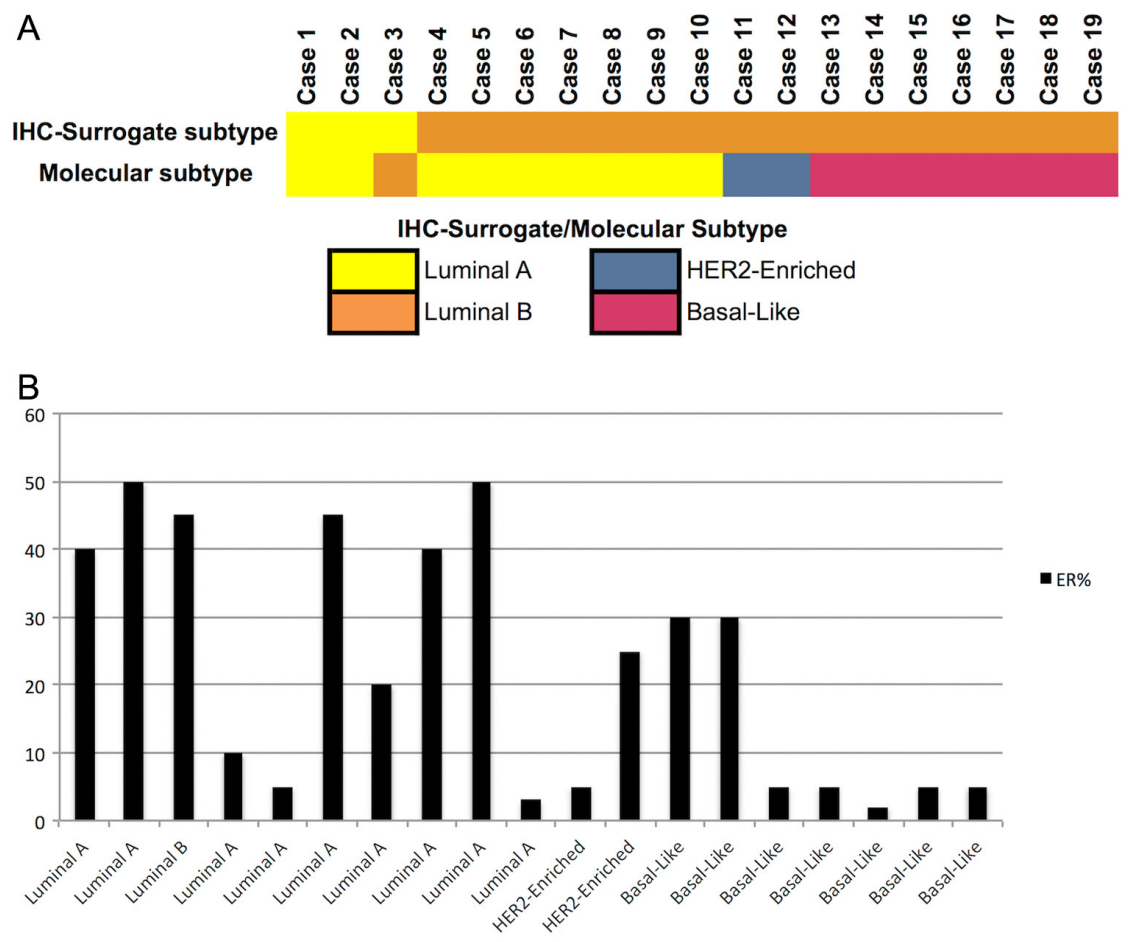

Figure 4

IHC-based vs intrinsic molecular subtypes. (A) Following guidelines recommendations, all BC with an AR/ER ratio $\geq 2$ (19 cases) were classified as luminal by IHC. However, the Prosigna-PAM50 assay changed the classification of 17 cases $(89.5 \%)$, almost half of them to the non-luminal subtypes. (B) Correlation of the ER percentage (ER\%) nuclear staining (IHC) and intrinsic molecular subtypes in BC with an AR/ER ratio $\geq 2$. test, which was used for model selection, the AR/ER ratio model received the lowest AIC score (DFI AIC $=378.8$, DSS $\mathrm{AIC}=139.7$ ), indicating that this model is more effective at providing prognostic information than the model with an ER cut-off at 10\% (DFI AIC=384.6, DSS AIC=145.9). Furthermore, although patients with lower ER levels were more likely to have $\mathrm{AR} / \mathrm{ER} \geq 2,56.2 \%$ of tumours $(9 / 16$ cases) with a high AR/ER ratio had a high ER level ( $\geq 10 \%)$.

\section{$A R / E R \geq 2$ and association with intrinsic molecular subtypes}

A Prosigna-PAM50 assay was performed on the 19 cases with a ratio $A R / E R \geq 2$ to evaluate their $R O R$ and molecular subtype. Twelve out of the 19 cases (63.2\%) resulted in intermediate or high-risk categories (high probability of distant recurrence at 10 years) (Table 4 ).

We then compared the IHC-based subtypes (Hammond et al. 2010, Coates et al. 2015) with the intrinsic molecular subtype obtained by the Prosigna-PAM50 assay and the percentage of ER expression. Three cases were classified as IHC luminal A (15.8\%) and 16 cases as luminal B (84.2\%). The concordance between the IHC subtypes and intrinsic molecular subtypes was very low $(k=0.0583)$ since only 2 cases $(10.5 \%)$ maintained the same subtype (luminal A) using the Prosigna-PAM50 assay. Molecular tests classified $47.4 \%$ of samples as luminal A, 5.3\% as luminal B, $10.5 \%$ as HER2-enriched and $36.8 \%$ as a basal-like subtype (Fig. 4A and Table 4). Thus, gene expression analysis showed that $47.4 \%$ of BCs with an AR/ER ratio $\geq 2$ were assigned to non-luminal subtypes (Fig. 2, Fig. 4A and Table 4). The correlation with the percentage of ER expression showed that 6 of the cases that switched from luminal to non-luminal had an $\mathrm{ER}<10 \%$, although two cases classified as luminal A by Prosigna-PAM50 assay had an $\mathrm{ER}<10 \%$ (2\% and 5\%, respectively) (Fig. 4B).

\section{Discussion}

In our study, we demonstrated that within ER+ BCs, the $\mathrm{AR} / \mathrm{ER}$ ratio may represent an additional independent prognostic marker. Specifically, we showed that BCs with an AR/ER ratio $\geq 2$ had a worse DFF and DSS. This particular subset of tumours is rare within ER+ BCs and, from the molecular point of view, they do not always fit with the luminal subtype.

The prognostic role of $\mathrm{AR}$ in $\mathrm{ER}+\mathrm{BC}$ has been extensively studied. Several authors have reported that AR expression in luminal cancers is associated with a better outcome compared to AR negative BCs (Park et al. 2011, Castellano et al. 2013, Kim et al. 2015, BozovicSpasojevic et al. 2016). However, some reports suggest that AR could be related to BC progression (Grogg et al. 2015), as it is detected in a significantly higher percentage of ductal carcinomas 'in situ' (DCIS) that are adjacent to invasive carcinomas than in pure DCIS (Yu et al. 2011). 
Moreover, although the expression of ER and PgR decrease during BC progression (from DCIS to invasive and from G1 to G3), AR expression is highly conserved during $\mathrm{BC}$ progression, as it is detected in a high percentage of metastatic tumours (Cimino-Mathews et al. 2012, Grogg et al. 2015). In addition, Gonzalez and coworkers (Gonzalez et al. 2008) found that AR+ tumours are frequently positive for matrix metalloproteinases (MMPs), which have been involved in breast tumour dissemination. Finally, a recent study indicated that AR expression can induce the epithelial-to-mesenchymal transition in $\mathrm{ER}+\mathrm{BC}$ cells, conferring them with metastatic potential (Feng et al. 2016).

Panet-Raymond and coworkers (Panet-Raymond et al. 2000) reported that co-expression of both ER and $\mathrm{AR}$ reduces the trans-activation function of $\mathrm{AR}$, and Takagi and coworkers (Takagi et al. 2010) suggested that AR signalling is suppressed in BC by high ER signalling activity.

All these results indicate that the interaction between the ER and AR levels may influence the AR activity. In line with this hypothesis, we found that BCs with a high AR/ER ratio are associated with aggressive biological features and worse prognosis.

To the best of our knowledge, only Cochrane and coworkers reported an association between AR/ER ratio and outcome (Cochrane et al. 2014). They showed that $\mathrm{AR} / \mathrm{ER}$ ratio $\geq 2$ is a good predictor of DFI and DSS, in a cohort of $\mathrm{ER}+\mathrm{BC}$ patients. AR/ER optimal ratio (AR/ER $\geq 2)$ was further defined and confirmed to predict DFI and DSS in our cohort (ER+/HER2- BC patients) by univariate Cox (HR) analysis. However, they reported a higher percentage of cases with an AR/ER ratio $\geq 2$ than in our series $(11.4 \%$ vs $6 \%$ respectively), which is probably related to differences in case selection since we excluded tumours with HER2 positivity.

The molecular analysis with Prosigna-PAM50 confirmed that most cases with $\mathrm{AR} / \mathrm{ER} \geq 2$ had a high-tointermediate ROR. In addition, Prosigna-PAM50 assay assigned $47.4 \%$ of our IHC luminal cases to the nonluminal intrinsic molecular subtypes. These results could suggest that tumours with a high AR/ER ratio could be resistant to hormone therapy. In fact, in vitro studies have demonstrated that hormone therapy-resistant tumours express higher levels of AR and lower ER levels than hormone therapy-sensitive tumours (De Amicis et al. 2010, Fujii et al. 2014, Rechoum et al. 2014, Ciupek et al. 2015). To confirm these experimental data, Cochrane and coworkers demonstrated that $\mathrm{AR} / \mathrm{ER} \geq 2$ was associated with an increased risk of tamoxifen therapy failure in
BC patients (Cochrane et al. 2014). Taken together, these data may suggest that BCs with an $A R / E R \geq 2$ could represent tumours that are changing or evolving from ER dependence (luminal subtype) to AR dependence, with the progressive loss of ER expression (non-luminal subtype).

Our study has some limitations due to its retrospective design. We included in the analysis patients with different treatment (hormone therapy and chemotherapy), and we do not have validation setting of patients to confirm our data. To address these limitations and validate our data, future studies need to include larger cohort of patients, who possibly underwent the same therapeutic approach.

In conclusion, our results suggest that tumours with $A R / E R \geq 2$ should be carefully evaluated and reinforce the idea of targeting AR for BC treatment.

\section{Supplementary data}

This is linked to the online version of the paper at https://doi.org/10.1530/ ERC-17-0417.

Declaration of interest

The authors declare that there is no conflict of interest that could be perceived as prejudicing the impartiality of the research reported.

\section{Funding}

This study was funded by 'Lega Italiana per la Lotta contro i Tumori' - LILT and by the Ministry of University bando ricerca locale ex-60\% anno 2016 to IC. NR was supported by Colciencias Grant (Call 617, Colombia. 2014).

\section{Author contribution statement}

Study conception and design: N R, M R L, L A, A S and I C.; Acquisition of data: N R, J M, M P M, L B, P C, S O A, I C.; Analysis and interpretation of data: N R, L A, S O A, M P M, L B, P C, A S; Drafting of manuscript: N R, $M R$ L, J M and I C.; Critical revision: N R, M R L, L A, S O A, J M, M P M, L B, $P C, A S$ and I C.; Final approval of the version to be submitted: N R, M R L, L A, SO A, J M, M P M, L B, P C, A S and I C.

\section{Acknowledgment}

The authors would like to acknowledge technical support in immunohistochemical procedures to Rosalia Russo and Marco Cupo.

\section{References}

Aleskandarany MA, Abduljabbar R, Ashankyty I, Elmouna A, Jerjees D, Ali S, Buluwela L, Diez-Rodriguez M, Caldas C, Green AR, et al. 2016 Prognostic significance of androgen receptor expression in invasive breast cancer: transcriptomic and protein expression analysis. Breast Cancer Research and Treatment 159 215-227. (https://doi.org/10.1007/ s10549-016-3934-5)
2018 Society for Endocrinology Published by Bioscientifica Ltd. Printed in Great Britain 
Ando S, De Amicis F, Rago V, Carpino A, Maggiolini M, Panno ML \& Lanzino M 2002 Breast cancer: from estrogen to androgen receptor. Molecular and Cellular Endocrinology 193 121-128. (https://doi. org/10.1016/S0303-7207(02)00105-3)

Asano Y, Kashiwagi S, Goto W, Tanaka S, Morisaki T, Takashima T, Noda S, Onoda N, Ohsawa M, Hirakawa K, et al. 2017 Expression and clinical significance of androgen receptor in triple-negative breast cancer. Cancers 9 4. (https://doi.org/10.3390/cancers9010004)

Birrell SN, Bentel JM, Hickey TE, Ricciardelli C, Weger MA, Horsfall DJ \& Tilley WD 1995 Androgens induce divergent proliferative responses in human breast cancer cell lines. Journal of Steroid Biochemistry and Molecular Biology 52 459-467. (https://doi.org/10.1016/09600760(95)00005-K)

Bozovic-Spasojevic I, Zardavas D, Brohee S, Ameye L, Fumagalli D, Ades F, de Azambuja E, Bareche Y, Piccart M, Paesmans M, et al. 2016 The prognostic role of androgen receptor in patients with early-stage breast cancer: a meta-analysis of clinical and gene expression data. Clinical Cancer Research 23 2707-2712. (https://doi. org/10.1158/1078-0432.CCR-16-0979)

Buchanan G, Birrell SN, Peters AA, Bianco-Miotto T, Ramsay K, Cops EJ, Yang M, Harris JM, Simila HA, Moore NL, et al. 2005 Decreased androgen receptor levels and receptor function in breast cancer contribute to the failure of response to medroxyprogesterone acetate. Cancer Research 65 8487-8496. (https://doi.org/10.1158/0008-5472. CAN-04-3077)

Bustreo S, Osella-Abate S, Cassoni P, Donadio M, Airoldi M, Pedani F, Papotti M, Sapino A \& Castellano I 2016 Optimal Ki67 cut-off for luminal breast cancer prognostic evaluation: a large case series study with a long-term follow-up. Breast Cancer Research and Treatment 157 363-371. (https://doi.org/10.1007/s10549-016-3817-9)

Castellano I, Allia E, Accortanzo V, Vandone AM, Chiusa L, Arisio R, Durando A, Donadio M, Bussolati G, Coates AS, et al. 2010 Androgen receptor expression is a significant prognostic factor in estrogen receptor positive breast cancers. Breast Cancer Research and Treatment 124 607-617. (https://doi.org/10.1007/s10549-010-0761-y)

Castellano I, Chiusa L, Vandone AM, Beatrice S, Goia M, Donadio M, Arisio R, Muscara F, Durando A, Viale G, et al. 2013 A simple and reproducible prognostic index in luminal ER-positive breast cancers. Annals of Oncology 24 2292-2297. (https://doi.org/10.1093/annonc/ mdt183)

Cimino-Mathews A, Hicks JL, Illei PB, Halushka MK, Fetting JH, De Marzo AM, Park BH \& Argani P 2012 Androgen receptor expression is usually maintained in initial surgically resected breast cancer metastases but is often lost in end-stage metastases found at autopsy. Human Pathology 43 1003-1011. (https://doi.org/10.1016/j. humpath.2011.08.007)

Ciupek A, Rechoum Y, Gu G, Gelsomino L, Beyer AR, Brusco L, Covington KR, Tsimelzon A \& Fuqua SA 2015 Androgen receptor promotes tamoxifen agonist activity by activation of EGFR in ERalpha-positive breast cancer. Breast Cancer Research and Treatment 154 225-237. (https://doi.org/10.1007/s10549-015-3609-7)

Coates AS, Winer EP, Goldhirsch A, Gelber RD, Gnant M, PiccartGebhart M, Thurlimann B, Senn HJ \& Panel M 2015 Tailoring therapies - improving the management of early breast cancer: St Gallen International Expert Consensus on the primary therapy of early breast cancer 2015. Annals of Oncology 26 1533-1546. (https://doi.org/10.1093/annonc/mdv221)

Cochrane DR, Bernales S, Jacobsen BM, Cittelly DM, Howe EN, D'Amato NC, Spoelstra NS, Edgerton SM, Jean A, Guerrero J, et al. 2014 Role of the androgen receptor in breast cancer and preclinical analysis of enzalutamide. Breast Cancer Research 16 R7. (https://doi. org/10.1186/bcr3599)

Cops EJ, Bianco-Miotto T, Moore NL, Clarke CL, Birrell SN, Butler LM \& Tilley WD 2008 Antiproliferative actions of the synthetic androgen, mibolerone, in breast cancer cells are mediated by both androgen and progesterone receptors. Journal of Steroid Biochemistry and Molecular Biology 110 236-243. (https://doi.org/10.1016/j.jsbmb.2007.10.014)

De Amicis F, Thirugnansampanthan J, Cui Y, Selever J, Beyer A, Parra I, Weigel NL, Herynk MH, Tsimelzon A, Lewis MT, et al. 2010 Androgen receptor overexpression induces tamoxifen resistance in human breast cancer cells. Breast Cancer Research and Treatment 121 1-11. (https://doi.org/10.1007/s10549-009-0436-8)

Dowsett M, Sestak I, Lopez-Knowles E, Sidhu K, Dunbier AK, Cowens JW, Ferree S, Storhoff J, Schaper C \& Cuzick J 2013 Comparison of PAM50 risk of recurrence score with oncotype DX and IHC4 for predicting risk of distant recurrence after endocrine therapy. Journal of Clinical Oncology 31 2783-2790. (https://doi. org/10.1200/JCO.2012.46.1558)

Early Breast Cancer Trialists' Collaborative Group, Davies C, Godwin J, Gray R, Clarke M, Cutter D, Darby S, McGale P, Pan HC, Taylor C, et al. 2011 Relevance of breast cancer hormone receptors and other factors to the efficacy of adjuvant tamoxifen: patient-level metaanalysis of randomised trials. Lancet 378 771-784. (https://doi. org/10.1016/S0140-6736(11)60993-8)

Feng J, Li L, Zhang N, Liu J, Zhang L, Gao H, Wang G, Li Y, Zhang Y, Li X, et al. 2016 Androgen and AR contribute to breast cancer development and metastasis: an insight of mechanisms. Oncogene 36 2775-2790. (https://doi.org/10.1038/onc.2016.432)

Fujii R, Hanamura T, Suzuki T, Gohno T, Shibahara Y, Niwa T, Yamaguchi Y, Ohnuki K, Kakugawa Y, Hirakawa H, et al. 2014 Increased androgen receptor activity and cell proliferation in aromatase inhibitor-resistant breast carcinoma. Journal of Steroid Biochemistry and Molecular Biology 144 513-522. (https://doi org/10.1016/j.jsbmb.2014.08.019)

Gonzalez LO, Corte MD, Vazquez J, Junquera S, Sanchez R, Alvarez AC, Rodriguez JC, Lamelas ML \& Vizoso FJ 2008 Androgen receptor expresion in breast cancer: relationship with clinicopathological characteristics of the tumors, prognosis, and expression of metalloproteases and their inhibitors. BMC Cancer 8149. (https://doi.org/10.1186/1471-2407-8-149)

Greeve MA, Allan RK, Harvey JM \& Bentel JM 2004 Inhibition of MCF-7 breast cancer cell proliferation by 5alpha-dihydrotestosterone; a role for p21(Cip1/Waf1). Journal of Molecular Endocrinology 32 793-810. (https://doi.org/10.1677/jme.0.0320793)

Grogg A, Trippel M, Pfaltz K, Ladrach C, Droeser RA, Cihoric N, Salhia B, Zweifel M \& Tapia C 2015 Androgen receptor status is highly conserved during tumor progression of breast cancer. $B M C$ Cancer 15 872. (https://doi.org/10.1186/s12885-015-1897-2)

Hammond ME, Hayes DF, Dowsett M, Allred DC, Hagerty KL, Badve S, Fitzgibbons PL, Francis G, Goldstein NS, Hayes M, et al. 2010 American Society of Clinical Oncology/College Of American Pathologists guideline recommendations for immunohistochemical testing of estrogen and progesterone receptors in breast cancer. Journal of Clinical Oncology 28 2784-2795. (https://doi.org/10.1200/JCO.2009.25.6529)

Hilborn E, Gacic J, Fornander T, Nordenskjold B, Stal O \& Jansson A 2016 Androgen receptor expression predicts beneficial tamoxifen response in oestrogen receptor-alpha-negative breast cancer. British Journal of Cancer 114 248-255. (https://doi.org/10.1038/bjc.2015.464)

Hu R, Dawood S, Holmes MD, Collins LC, Schnitt SJ, Cole K, Marotti JD, Hankinson SE, Colditz GA \& Tamimi RM 2011 Androgen receptor expression and breast cancer survival in postmenopausal women. Clinical Cancer Research 17 1867-1874. (https://doi. org/10.1158/1078-0432.CCR-10-2021)

Jiang HS, Kuang XY, Sun WL, Xu Y, Zheng YZ, Liu YR, Lang GT, Qiao F, Hu X \& Shao ZM 2016 Androgen receptor expression predicts different clinical outcomes for breast cancer patients stratified by hormone receptor status. Oncotarget 7 41285-41293. (https://doi. org/10.18632/oncotarget.9778)

Kim Y, Jae E \& Yoon M 2015 Influence of androgen receptor expression on the survival outcomes in breast cancer: a meta-analysis. Journal of (c) 2018 Society for Endocrinology Published by Bioscientifica Ltd. Printed in Great Britain 
Breast Cancer 18 134-142. (https://doi.org/10.4048/

jbc.2015.18.2.134)

Lin HY, Sun M, Lin C, Tang HY, London D, Shih A, Davis FB \& Davis PJ 2009 Androgen-induced human breast cancer cell proliferation is mediated by discrete mechanisms in estrogen receptor-alpha-positive and -negative breast cancer cells. Journal of Steroid Biochemistry and Molecular Biology 113 182-188. (https://doi.org/10.1016/j. jsbmb.2008.12.010)

Luo X, Shi YX, Li ZM \& Jiang WQ 2010 Expression and clinical significance of androgen receptor in triple negative breast cancer. Chinese Journal of Cancer 29 585-590. (https://doi.org/10.5732/ cjc.009.10673)

Macedo LF, Guo Z, Tilghman SL, Sabnis GJ, Qiu Y \& Brodie A 2006 Role of androgens on MCF-7 breast cancer cell growth and on the inhibitory effect of letrozole. Cancer Research 66 7775-7782. (https://doi.org/10.1158/0008-5472.CAN-05-3984)

Marchio C, Lambros MB, Gugliotta P, Di Cantogno LV, Botta C, Pasini B, Tan DS, Mackay A, Fenwick K, Tamber N, et al. 2009 Does chromosome 17 centromere copy number predict polysomy in breast cancer? A fluorescence in situ hybridization and microarraybased CGH analysis. Journal of Pathology 219 16-24. (https://doi. org/10.1002/path.2574)

Need EF, Selth LA, Harris TJ, Birrell SN, Tilley WD \& Buchanan G 2012 Research resource: interplay between the genomic and transcriptional networks of androgen receptor and estrogen receptor alpha in luminal breast cancer cells. Molecular Endocrinology 26 1941-1952. (https://doi.org/10.1210/me.2011-1314)

Niemeier LA, Dabbs DJ, Beriwal S, Striebel JM \& Bhargava R 2010 Androgen receptor in breast cancer: expression in estrogen receptorpositive tumors and in estrogen receptor-negative tumors with apocrine differentiation. Modern Pathology 23 205-212. (https://doi. org/10.1038/modpathol.2009.159)

Panet-Raymond V, Gottlieb B, Beitel LK, Pinsky L \& Trifiro MA 2000 Interactions between androgen and estrogen receptors and the effects on their transactivational properties. Molecular and Cellular Endocrinology 167 139-150. (https://doi.org/10.1016/S03037207(00)00279-3)

Park S, Koo J, Park HS, Kim JH, Choi SY, Lee JH, Park BW \& Lee KS 2010 Expression of androgen receptors in primary breast cancer. Annals of Oncology 21 488-492. (https://doi.org/10.1093/annonc/mdp510)

Park S, Koo JS, Kim MS, Park HS, Lee JS, Lee JS, Kim SI, Park BW \& Lee KS 2011 Androgen receptor expression is significantly associated with better outcomes in estrogen receptor-positive breast cancers. Annals of Oncology 22 1755-1762. (https://doi.org/10.1093/annonc/ mdq678)

Parker JS, Mullins M, Cheang MC, Leung S, Voduc D, Vickery T, Davies S, Fauron C, He X, Hu Z, et al. 2009 Supervised risk predictor of breast cancer based on intrinsic subtypes. Journal of Clinical Oncology 27 1160-1167. (https://doi.org/10.1200/ JCO.2008.18.1370)

Peters AA, Buchanan G, Ricciardelli C, Bianco-Miotto T, Centenera MM Harris JM, Jindal S, Segara D, Jia L, Moore NL, et al. 2009 Androgen receptor inhibits estrogen receptor-alpha activity and is prognostic in breast cancer. Cancer Research 69 6131-6140. (https://doi. org/10.1158/0008-5472.CAN-09-0452)

Pistelli M, Caramanti M, Biscotti T, Santinelli A, Pagliacci A, De Lisa M, Ballatore Z, Ridolfi F, Maccaroni E, Bracci R, et al. 2014 Androgen receptor expression in early triple-negative breast cancer: clinical significance and prognostic associations. Cancers 6 1351-1362. (https://doi.org/10.3390/cancers6031351)

Rechoum Y, Rovito D, Iacopetta D, Barone I, Ando S, Weigel NL, O'Malley BW, Brown PH \& Fuqua SA 2014 AR collaborates with ERalpha in aromatase inhibitor-resistant breast cancer. Breast Cancer Research and Treatment 147 473-485. (https://doi.org/10.1007/ s10549-014-3082-8)

Sapino A, Marchio C, Senetta R, Castellano I, Macri L, Cassoni P, Ghisolfi G, Cerrato M, D'Ambrosio E \& Bussolati G 2006 Routine assessment of prognostic factors in breast cancer using a multicore tissue microarray procedure. Virchows Archiv 449 288-296. (https://doi.org/10.1007/s00428-006-0233-2)

Takagi K, Miki Y, Nagasaki S, Hirakawa H, Onodera Y, Akahira J, Ishida T, Watanabe M, Kimijima I, Hayashi S, et al. 2010 Increased intratumoral androgens in human breast carcinoma following aromatase inhibitor exemestane treatment. Endocrine-Related Cancer 17 415-430. (https://doi.org/10.1677/ERC-09-0257)

Vera-Badillo FE, Templeton AJ, de Gouveia P, Diaz-Padilla I, Bedard PL, Al-Mubarak M, Seruga B, Tannock IF, Ocana A \& Amir E 2014 Androgen receptor expression and outcomes in early breast cancer: a systematic review and meta-analysis. Journal of the National Cancer Institute 106 djt319. (https://doi.org/10.1093/jnci/djt319)

Yu Q, Niu Y, Liu N, Zhang JZ, Liu TJ, Zhang RJ, Wang SL, Ding XM \& Xiao XQ 2011 Expression of androgen receptor in breast cancer and its significance as a prognostic factor. Annals of Oncology 22 1288-1294. (https://doi.org/10.1093/annonc/mdq586)

Received in final form 23 November 2017

Accepted 4 December 2017 (c) 2018 Society for Endocrinology Published by Bioscientifica Ltd. Printed in Great Britain 